\title{
Insulinoma masquerading as carotid transient ischaemic attacks
}

\author{
V. L. U. ILLANGASEKERA \\ M.D., M.R.C.P.
}

Department of Neurology, Chapel Allerton Hospital, Leeds 7

\begin{abstract}
Summary
A patient who initially presented with classical internal carotid territory transient ischaemic attacks, on further investigations was found to have an insulinoma, the removal of which completely alleviated the symptoms. This appears to be an unusual form of presentation of a rare tumour. The possible mechanisms of focal neurological disturbances during hypoglycaemia are discussed.
\end{abstract}

\section{Introduction}

The clinical features of insulinoma are attributed to episodes of hypoglycaemia, associated with generalized or focal cerebral dysfunction. Focal disturbances may produce symptoms that mimic various syndromes of cerebrovascular insufficiency. Transient hemiplegia, dysphasia and hemianopia have been observed in association with insulin secreting pancreatic adenomata (Service et al., 1976; Garland, 1958; Richardson and Hill, 1957; Skillern and Rynearson, 1953).

A patient is reported, who presented with transient blindness and dysphasia suggestive of carotid transient ischaemic attacks (TIAs), who was subsequently found to have an insulinoma. To the author's knowledge this mode of presentation of an insulinoma has not been previously reported.

\section{Case report}

A previously fit 52-year-old right-handed man presented with a 6-month history of episodes of dysphasia and loss of vision of his left eye lasting for $15-30 \mathrm{~min}$. On an average, he suffered 3 such attacks each month. He was a non-smoker. There was nothing relevant in the past medical or family histories. The patient had no other neurological complaints and no symptoms on systematic enquiry. He was normotensive and had no carotid or cardiac bruits. Neurological and general examination were normal except for moderate obesity. Investigations: $\mathrm{Hb} 15.2 \mathrm{~g} / \mathrm{dl}$; ESR $16 \mathrm{~mm}$ in the 1st hour; WBC $8.2 \times 10^{9} / 1$ with a normal differential count; random serum glucose $4.4 \mathrm{mmol} / 1$; normal serum urea, electrolytes and liver function tests; fasting cholesterol $6.3 \mathrm{mmol} / 1$ (normal range $3.5-8 \mathrm{mmol} / \mathrm{l}$ ) fasting triglycerides $2 \cdot 1 \mathrm{mmol} / 1$ (normal range lessir. than $1.7 \mathrm{mmol} / \mathrm{l})$. Wassermann reaction was negative. ECG, chest and skull X-rays and EEG were normal, the latter showing no focal discharges. An $\operatorname{arch}_{\tilde{N}}^{\circ}$ aortogram with bilateral carotid arteriography did
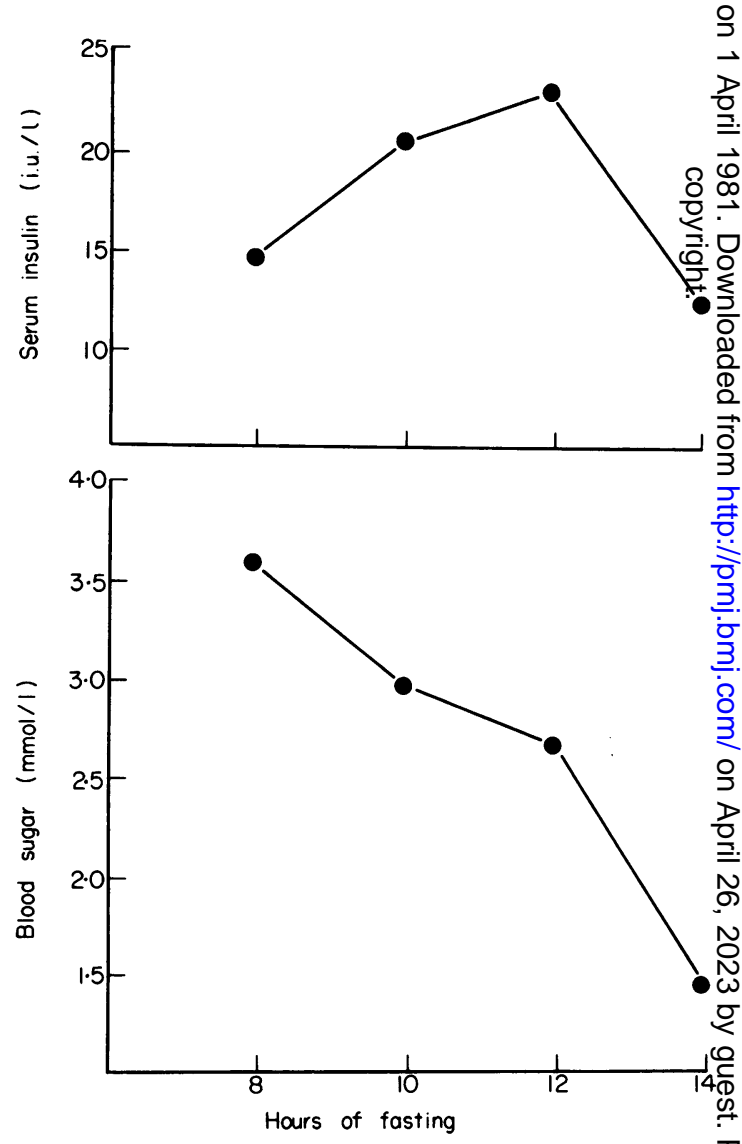

FIG. 1. Initial rise in serum insulin level despite a falling blood glucose, indicating an abnormal glucose-insulin homoeostatic relationship. 
not reveal a structural abnormality. The patient was treated with aspirin and dipyrimadole with no alteration in the nature or frequency of attacks. A few months after the onset of symptoms he was readmitted with sudden onset of disturbed behaviour. On examination he was afebrile, confused and disorientated. There were no localizing neurological signs and general examination was unremarkable.

A serum glucose estimation at this time was 1.0 $\mathrm{mmol} / \mathrm{l}$. There was a dramatic improvement with $50 \mathrm{ml}$ of $50 \%$ dextrose administered intravenously. In view of these observations a prolonged fasting test was performed and after $14 \mathrm{hr}$ the patient developed amaurosis of the left eye and dysphasia. Within minutes he became unresponsive and the corresponding blood sugar was $1.5 \mathrm{mmol} / \mathrm{l}$. There was a rapid reversal of the clinical signs with $50 \mathrm{ml}$ of $50 \%$ dextrose given intravenously. During the period of fasting, serial samples of blood were taken for serum glucose and insulin estimations. The serum insulin values rose while the blood sugar was approaching the hypoglycaemic range (Fig. 1). This indicated an abnormal glucose-insulin homoeostatic relationship which was suggestive of the presence of autonomous insulin-producing tissue (Fajans, 1977).

An intravenous tolbutamide test confirmed the presence of endogenous hyperinsulinism. A pancreatic arteriogram demonstrated a tumour, $1.5 \mathrm{~cm}$ in diameter, near the tail of the pancreas (Fig. 2)

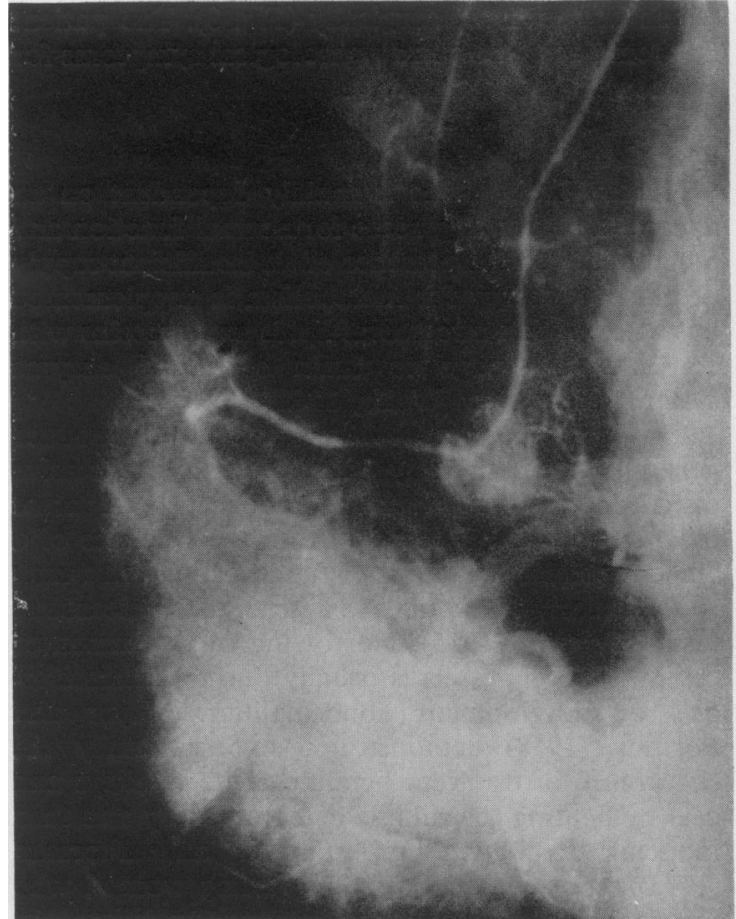

Fig. 2. Pancreatic arteriogram demonstrating the insulinoma in the tail of the pancreas adjacent to the hilum of the spleen.

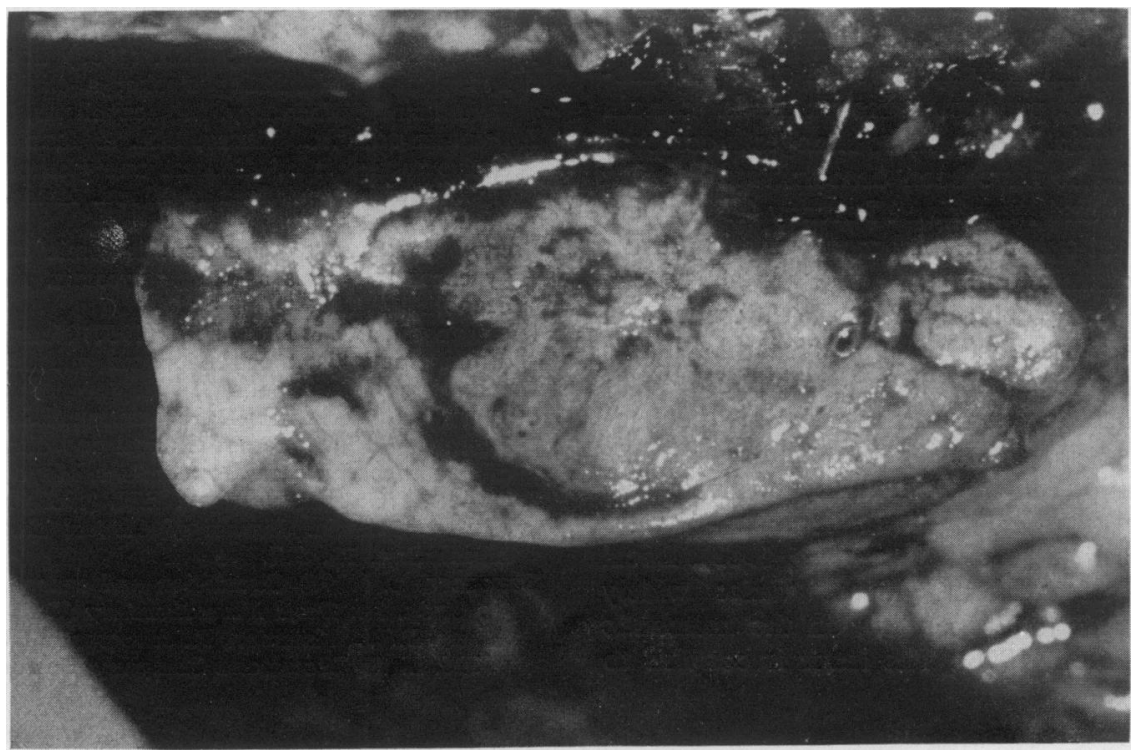

Fig. 3. Tail of the pancreas with the insulinoma in situ $(\times 5)$. 
which was removed surgically (Fig. 3 ). The patient has remained free from neurological symptoms for 12 months postoperatively.

\section{Disussion}

Human brain tissue is mainly dependent on an adequate supply of glucose for normal function and metabolism. In the presence of an insufficient supply of glucose, energy for metabolism is supplemented by the oxidation of cerebral lipids and proteins with consequent damage to brain cells and enzyme systems (Elliot and Wolfe, 1962).

Hypoglycaemia would be expected to produce generalized cerebral dysfunction with progressive disturbance of consciousness. The development of focal symptoms might arise from the presence of a clinically silent structural or functional lesion which is particularly susceptible to a generalized metabolic insult (Portnoy, 1965). Narrowing of the lumen of cerebral blood vessels is usually due to atherosclerosis or development abnormalities. Meyer and Portnoy (1958) demonstrated experimentally the occurrence of transient hemiplegia in monkeys and cats by ligating the middle cerebral artery and then inducing hypoglycaemia. Fischer and Florman (1943) reported the case of a young woman who recovered from hemiplegia due to embolism but later developed transient hemiplegia during insulininduced hypoglycaemia. In the present patient the macroscopic carotid circulation and its bifurcations were shown to be anatomically normal at angiography.

Several authors have suggested that vasospasm may cause localized cerebral ischaemia (Fischer and Florman, 1943; Courville, 1957). Courville postulated that hypoglycaemia may act upon a cerebral vasomotor centre to produce vasospasm in certain regions of the brain. However, no changes in cerebrovascular resistance have been demonstrated during hypoglycaemia and Meyer and Portnoy (1958) were unable to detect spasm of pial vessels during direct microscopic examination.

Brain cells may exhibit intrinsic differences in vulnerability to the effects of hypoglycaemia. If this is the case, focal cerebral disturbances could occur during generalized hypoglycaemia. Possible mechanisms include local alteration in cellular enzyme systems, variations in the availability of alternative energy sources or changes in regional glucose demands (Kornfeld, 1959; Goodman, 1953). Local consumption of cerebral glucose varies widely throughout the brain depending on the metabolic demands (Sokoloff, 1976). The latter is coupled to local functional activity (Pappenheimer, Heisey? and Jordan, 1961) and since the brain is not com posed of functionally homogenous tissue, it is possible for the effects of hypoglycaemia to be felt. more in certain areas than others. Even though it is not known how exactly the neurones thus affectedo produce cerebral disturbances, this appears to beo the most plausible mechanism that explains the occurrence of focal dysfunction during generalized $\frac{1}{2}$ hypoglycaemia.

\section{Acknowledgments}

I thank Dr S. Currie, Consultant Neurologist, for his per $\overrightarrow{\vec{\omega}}$ mission to publish this case.

\section{References}

Courville, C.B. (1957) Late cerebral changes incident tosevere hypoglycemia (insulin shock). Archives of Neurology. and Psychiatry, 78, 1.

Elliot, K.A.C. \& Wolfe, L.S. (1962) Brain tissue respiration and glycolysis. In: Neurochemistry, (Ed by Elliott, K.A.C. N Page, I.H. \& Quastel, J.H.) 3rd edn, p. 177-212. Charleso C. Thomas, Springfield, Illinois.

FaJANs, S.S. (1977) Hyperinsulinism, hypoglycemia and glucagon secretion. In: Harrison's Principles of Internat Medicine, (Ed by Thorn, G.W., Adams, R.D., Braunwald E., Isselbacher, K.J. \& Petersdorf, R.G.) 8th edn, p. $588 \overrightarrow{-}$ McGraw-Hill, New York.

Fischer, A.E. \& Florman, A.L. (1943) Transitory he⿻ి.冂 plegia associated with hypoglycemia in a diabetic ch with congenital heart disease. American Journal of Disedises of Children, 65, 73.

GARLAND, H. (1958) Endogenous hypoglycaemia. Proceedings of the Royal Society of Medicine, 51, 979.

GoodMaN, J.I. (1953) Review: Insulin (hypoglycemic) reactions in diabetic patients. Metabolism, 2, 485.

KORNFELD, P. (1959) Spontaneous hypoglycemia. New York State Journal of Medicine, 59, 2190.

MEYER, J.S. \& PORTNOY, H.D. (1958) Localized cerebra hypoglycemia simulating stroke; a clinical and experi mental study. Neurology. Minneapolis, 8, 601 .

PAPPENheimer, J.R., HeISEY, S.R. \& JoRDAN, E.F. (1961) Active transport of diodrast and phenolsulforphthalein from cerebrospinal fluid to blood. American Journal of Physiology, 200, 1.

PoRTNOY, H.D. (1965) Transient 'ischemic' attacks produced. by carotid stenosis and hypoglycemia. Neurology. Minneapolis, $15,830$.

RichaRDSON, J.C. \& Hill, F.M. (1957) Neurologic diagnosiso of pancreatic islet cell adenoma with hyperinsulinism Neurology. Minneapolis, 7, 793.

Service, E.J., Dale, A.J.D., Elveback, L.R. \& Nai-Siang JIANG (1976) Insulinoma: Clinical and diagnostic features of 60 consecutive cases. Proceedings. Mayo Clinic, 51, 417.

SkILleRN, P.G. \& RYNEARSON, E.H. (1953) Medical aspects of hypoglycemia. Journal of Clinical Endocrinology and Metabolism, 13, 587.

SoKolofF, L. (1976) Circulation and energy metabolism ofo the brain. In: Basic Neurochemistry (Ed by Siegel, G.J., Albers, R.W., Katzman, R. \& Agranoff, B.W.), 2nd edn p. 396. Little, Brown and Company, Boston. 